\title{
Pendampingan Pengembangan Produk Dan Manajemen Usaha Pada Kube Jamu Gendong Grogol Sukoharjo Dalam Meningkatkan Kemandirian Ekonomi Masyarakat
}

\author{
Setyani Sri Haryanti ${ }^{1}$ Anggoro Panji Nugroho ${ }^{2}$ \\ STIE AUB Surakarta ${ }^{1,2}$
}

\begin{abstract}
ABSTRAK
Tujuan Pengabdian Kepada Masyarakat ini adalah untuk meningkatkan kesejahteraan masyarakat di Desa Gogol Kabupaten Sukoharjo. Tim mengadakan observasi pada tanggal 8 Juli 2020. Kemudian dilakukan pendampingan terhadap Kube Jamu Gendong Seger Waras. Ceramah materi di berikan 8 Agustus 2020. Partisipasi keluarga sangat dibutuhkan dalam mendukung perekonomian yaitu dengan pembentukan kelompok- kelompok usaha mandiri yang mampu menghasilkan produk yang dapat dijual untuk menambah pendapatan keluarga. Usaha jamu tradisional atau jamu gendong adalah salah satu wadah yang dapat menghimpun ibu-ibu rumah tangga dalam meningkatkan pendapatnnya.. Permasalahan yang sering ditemui pada masyarakat adalah banyaknya masyarakat yang tidak memahami tujuan dan manfaat dari jamu gendong secara luas, manajemen usaha dan pengembangan produk jamu gendong. Munculnya pesaing saat ini dengan pengelolaan modern. Perusahaan dengan investasi besar menjual jamu tradisional dalam kemasan dan proses produksi lebih modern. Kompetitor baru ini kini menjadi pengganti peran mbok jamu. Peran serta perempuan di bidang ekonomi merupakan salah satu indikator meningkatnya kesejahteraan dalam keluarga. Banyak perempuan besekolah kejenjang yang lebih tinggi, dan mereka dengan sendirinya bebas memilih untuk bekerja di luar rumah. Dengan adanya perempuan bekerja diluar rumah, juga merupakan indicator pendapatan dalam keluarga meningkat. Kaum perempuan memiliki peran dalam mengurangi kemiskinan melalui pemberdayaan perempuan dalam kelompok wirausaha rumah tangga. Usaha produktif jamu gendong yang dilakukan merupakan bukti, bahwa perempuan dapat membantu meningkatkan kesejahteraan keluarganya rumah tangga. Perlu langkah yang tepat untuk menciptakan dari hal yang terkecil yaitu mensejahterakan keluarga dengan berpedoman kepada visi gerakan PKK. PKK Desa Grogol Kabupaten Sukoharjo merupakan salah satu wadah organisasi perempuan. Latar belakang pendidikan ibu-ibu PKK tersebut beragam dan sebagian besar adalah ibu rumah tangga dengan keadaan ekonomi keluarga yang berada pada ekonomi bawah dan menengah. Pendekatan yang ditawarkan untuk menyelesaikan permasalahan yang dihadapi adalah dengan penyuluhan, pelatihan dan pendampingan manajemen usaha dan pengembangan produk jamu gendong
\end{abstract}

\section{A. PENDAhuluan}

Kesehatan adalah merupakan salah satu dari sekian banyak komponen lain yang berperan dalam meningkatkan kualitas sumber daya manusia yang untuk mendukung keberhasilan pembangunan Indonesia secara luas. Kesehatan seseorang sangat penting dalam menjalankan aktivitas kegiatan, termasuk hal yang dibutuhkan dalam mendukung hidupnya perekonomian. Banyak cara masyarakat secara individu untuk tetap sehat. Hal yang sering dilakukan adalah dengan minum jamu tradisional yang biasa dijual oleh pedang dengan istilah "jamu gendong". Usaha jamu gendong di era sekarang masih memiliki potensi yang cukup besar, baik di desa maupun di perkotaan di wilayah Indonesia. Usaha "jamu gendong" merupakan aktivitas usaha yang dilakukan perseorangan, dengan menggunakan bahan dasar rempah-rempah, maupun bahan tumbuhan yang berada di wilayah sekitar yang kemudian diolah melalui sebuah proses menjadi bentuk cairan yang dibuat segar yang dijajakan langsung kepada konsumen. (Liputan 6, BPOM, 14 Jan 2018). Pembentukan kelompok kelompok usaha mandiri seperti jamu gendong mampu menghasilkan produk yang dapat dijual untuk menambah pendapatan keluarga.

Penjual jamu gendong didominasi perempuan. Hingga saat ini usaha jamu gendong masih bertahan, di era yang lain sudah serba modern. Sejarah jamu tradisional 
atau menjadi jamu kemasan dalam gendong, merupakan kreasi masyarakat Indonesia sejak jaman dahulu. Wilayah Indonesia yang cukup luas dan ada keterbatasan dalam media transportasi serta komunikasi menjadikan pelayanan kesehatan mengalami sedikit kesulitan sampai ke pelosok wilayah. Pelayanan kesehatan yang yang masih terbatas membuat masyarakat yang tinggal di wilayah desa, mencari cara sendiri untuk menyembuhkan sakitnya. Praktik-praktik pengobatan di desa yaitu dengan menggunakan ramuan bahan yang tersedia di wilayah terserbut atau dengan kombinasi empon-empon. Masyarakat yang mengalami kesulitan untuk mendapatkan pengobatan, memakai alternative jamu.

Sistem distribusi jamu, awalnya dilakukan oleh laki-laki. Laki-laki mendistribusikan jamu dengan memikulnya, sementara kaum perempuan mendistribusikan jamu dengan cara menggendongnya. Selanjutnya distribusi jamu hanya dilakukan oleh kaum perempuan saja. Tenaga laki-laki dianggap lebih baik untuk pekerjaan lain seperti di pertanian.

Usaha jamu dari waktu kewaktu diyakini masyarakat cukup menguntungkan. Masyarakat mulai menjual jamu buatan sendiri. Yang akhirnya banyak menarik minat perempuan lain untuk ikut berjualan. Resep-resep jamu yang diperoleh dari para para pendahulu tersebut mulai ditularkan dari mulut ke mulut sehingga semakin banyak orang yang mengetahuinya.

Terjadinya urbanisasi penduduk desa yang pindah ke kota, untuk mengadu nasib dengan cara menjadi buruh atau berdagang, demikian juga para penjual jamu tersebut. Dalam perkembangannya, para penjual jamu ini memahami konsumen yang dilayani berbeda-beda, jenis jamu yang dijual akhirnya dissuaiakan dengan kebutuhan konsumen atau masyarakat. Seperti seperti cabe puyang, beras kencur, temu lawak, kunir asem, godhong kates (daun pepaya) dan masih banyak jenis yang lainnya. Saat ini jenis jamu yang dijual oleh penjual jamu semakin banyak. Meskipun demikian, mereka tetap mengembangkan resep-resep yang diturunkan oleh para leluhur.

Sampai saat ini usaha jamu gendong masih bisa bertahan. Jumlah mbok jamu gendong sedikit berkurang. Saat ini, terjadi inovasi kreativitas masyarakat penjual jamu gendong. Kreativitas dilakukan dalam mengemas saluran distribusi penjualan kepada masyarakat selaku konsumen jamu gendong, dengan menjajakan jamu memakai alat transportasi sepeda angin, sepeda motor maupun gerobak atau bahkan dengan kios atau toko.

Munculnya jamu tradisonal yang dikemas secara modern atau dalam bentuk sachet, para penjual jamu gendong tetap bisa bertahan dengan menjual secara kolaborasi baik yang dalam bentuk sachet maupun botol.

Desa Grogol merupakan salah satu sebuah desa kalurahan wilayah Kecamatan Grogol di Kabupaten Sukoharjo, Jawa Tengah. Dengan letak lokasi di bagian utara Kabupaten Sukoharjo, berbatasan dengan Kota Surakarta. Desa Grogol memiliki area yang cukup strategis karena dekat dengan Kota Surakarta. Serta memiliki akses yang dengan mudah menghubungkan wilayah lain ke daerah-daerah sekitarnya misalnya ke daerah, Boyolali, Klaten, dan Karanganyar, serta menuju ke arah Yogyakarta.

Desa Grogol memiliki susunan tanah yang cukup subur dan merupakan daerah pertanian yang cukup bagus, tetapi karena perkembangan jaman, letak yang strategis Desa Grogol pada khususnya dan Sukoharjo secara luas bergeser menjadi daerah perkotaan dan bisnis. Area pusat perbelanjaan, Perhotelan, Rumah Sakit, Pendidikan, dan Industri. Berbagai jenis Home Industri di Grogol antara lain industri kulit, tenun dan gitar. Kondisi perkoperasian di Kabupaten Sukoharjo secara kuantitatif terjadi penurunan, hal ini disebabkan terbitnya SK Menkop UKM RI, dari 429 koperasi yang masih aktif, memiliki anggota sebanyak 115.224 orang dan memiliki modal sendiri Rp300 miliar, omzet Rp500 miliar dan menghasilan SHU Rp24,19 miliar rupiah. Jumlah 
UMKM sendiri mencapai 18.592 unit yang terdiri dari skala mikro 12.934 unit, skala kecil 5.045, dan skala menengah 613 unit.

Total aset UMKM mencapai Rp1,24 triliun rupiah dengan omzet mencapai Rp3,4 triliun. Pemkab Sukoharjo telah memberikan dukungan besar dalam hal pemberdayaan koperasi dan UMKM. Yang terbaru adalah memprakarsasi terbentuknya 167 koperasi baru (Program Keluarga Harapan) berbasis perempuan.Tiap-tiap koperasi mendapat bantuan berupa hibah modal kerja Rp12 juta. Nilai total bantuan mencapai Rp2,1 miliar Rupiah. Bantuan serupa berupa modal kerja koperasi juga telah digulirkan sejak 2016 dan terus berlanjut hingga disediakannya gedung baru yang cukup megah dan siap mendukung PLUT atau pusat layanan usaha terpadu Koperasi dan UMKM Mandiri di Gedung P3D atau pusat promosi potensi daerah Graha Wijaya. Seluruh Gerakan Koperasi di Kabupaten Sukoharjo, baik yang produsen, konsumen, jasa maupun simpan pinjam untuk terus bergerak menjadi usaha yang moden tanpa meninggalkan jati diri. Kelompok Usaha Bersama (KUBE) merupakan kelompok keluarga miskin yang dibentuk, tumbuh, dan berkembang atas prakarsanya dalam melaksanakan Usaha Ekonomi Produktif (UEP) untuk meningkatkan pendapatan dan kesejahteraan sosial keluarga.

Usaha Ekonomi Produktif (UEP) adalah bantuan sosial yang diberikan kepada kelompok usaha bersama untuk meningkatkan pendapatan dan kesejahteraan sosial keluarga. KUBE beranggotakan 5 sampai 20 Kepala Keluarga dari masyarakat miskin yang masuk dalam Data Terpadu Penanganan Fakir Miskin dan Orang Tidak Mampu (DTPFMOTM).

Keberdayaan perempuan di bidang ekonomi adalah salah satu indikator meningkatnya kesejahteraan keluarga. Perempuan yang memiliki pendidikan tinggi, ratarata akan memilih bekerja diluar rumah dan bebas untuk menentukan kinerjanya, bekerja serta mempunyai pendapatan mandiri. Perempuan mempunyai peran dalam kegiatan mengurangi kemiskinan melalui berkarya dalam pemberdayaan masyarakat dan kelompok wirausaha terutama dalam UMKM.

PKK Desa Grogol Kecamatan Grogol Kabupaten Sukoharjo merupakan salah satu wadah organisasi perempuan. Latar belakang pendidikan ibu-ibu PKK tersebut beragam (lulusan SLTA dan perguruan tinggi), dan sebagian besar adalah ibu rumah tangga dengan keadaan ekonomi keluarga yang berada pada ekonomi menengah.

\section{Identifikasi Dan Perumusan Masalah}

Identifikasi masalah

Berpijak dari uraian diatas yang menjadi masalah adalah:

1. Belum sepenuhnya masyarakat khususnya ibu-ibu memahami manfaat usaha dalam menambah penghasilan keluarga, khususnya usaha jamu gendong.

2. Masyarakat khususnya ibu-ibu belum mengetahui bagaimana pengembangan produk dan tata cara manajemen usaha jamu gendong.

3. Masih kurangnya kesadaran masyarakat khususnya ibu-ibu untuk ikut berpartisipasi menjadi anggota Kube jamu gendong.

Perumusan Masalah

1. Bagaimanakah memberikan pemahaman kepada masyarakat khususnya ibu-ibu manfaat usaha dalam menambah penghasilan keluarga, khususnya usaha jamu gendong.

2. Bagaimanakah memberikan pengetahuan mayarakat khususnya ibu-ibu bagaimana pengembangan produk dan tata cara manajemen usaha jamu gendong.

3. Bagimanakah meningkatkan kesadaran masyarakat khususnya ibu-ibu untuk ikut berpartisipasi menjadi anggota Kube jamu gendong. 
2. Tujuan Kegiatan

1. Membangun kesadaran masyarakat khususnya ibu-ibu akan pentingnya manfaat usaha dalam menambah penghasilan keluarga, khususnya usaha jamu gendong

2. Memberi pengetahuan kepada masyarakat khususnya ibu-ibu bagaimana pengembangan produk dan tata cara manajemen usaha jamu gendong.

3. Membantu masyarakat khususnya ibu-ibu untuk ikut berpartisipasi menjadi anggota Kube jamu gendong.

\section{Manfaat Kegiatan}

Setelah masyarakat khususnya ibu-ibu mengetahui manfaat pengembangan produk jamu gendong dan tata cara manajemen usaha jamu gendong di era persaingan usaha saat ini, diharapkan akan menumbuhkan minat untuk mendirikan menjadi anggota Kube jamu gendong di Desa Grogol Kecamatan Grogol, Kabupaten Sukoharjo.

\section{Target}

Sasaran kegiatan pengabdian kepada masyarakat adalah ibu ibu Kelompok Usaha Bersama Jamu Gendong Seger Waras, PKK Desa Grogol Kabupaten Sukoharjo.

5. Luaran

Jurnal Pengabdian Kepada Masyarakat

\section{Solusi Yang Ditawarkan}

Usaha jamu gendong memiliki banyak manfaat salah satunya adalah meningkatkanperekonomian wilayah serta kesejahteraan dan perekonomian masyarakat anggota Kube. Masyarakat desa khususnya ibu-ibu diharapkan mau menambah pendapatan keluarga dengan usaha jamu gendong. Masyarakat harus didorong untuk mau menambah pendapatan keluarga dengan usaha jamu gendong didaerah mereka masingmasing.

Beberapa permasalahan pada masyarakat khususnya ibu-ibu adalah banyaknya masyarakat yang tidak atau belum seluruhnya mengerti serta memahami tujuan dan manfaat dari usaha jamu gendong. Peranan usaha jamu gendong dalam menunjang perekonomian masyarakat harus dimaksimalkan, terlebih dengan menjamurnya usaha kecil kreatif lainnya yang ada dapat dikategorikan sukses. Alternatif pemecahan masalah dilakukan dengan mengadakan pendampingan serta penyuluhan mengenai pengembangan produk dan manajemen usaha melalui Kube jmu gendong dan kader PKK di Grogol Kabupaten Sukoharjo.

Kegiatan ini dilakukan secara bertahap, mulai dari observasi awal dan koordinasi awal sampai monitoring dan evaluasi, sesudah dilakukan pendampingan oleh tim,

Pendekatan yang ditawarkan untuk menyelesaikan permasalahan yang dihadapi adalah dengan:

1. Rapat koordinasi persiapan Kegiatan Pengabdian dan menentukan scedule kegiatan.

2. Memberikan pemahaman tentang penambahan pendapatan keluarga.

3. Memberikan pemahaman manfaat usaha jamu gendong.

4. Memberikan penyuluhan tentang pengembangan produk jamu gendong.

5. Memberikan penyuluhan manajemen usaha jamu gendong.

6. Memberikan pendampingan pengembangan produk jamu gendong.

7. Memberikan pendampingan manajemen usaha jamu gendong. 


\section{B. METODE PENGABDIAN}

Metoda yang digunakan untuk mengatasi permasalahan diatas dapat dilihat pada tabel berikut :

\begin{tabular}{|l|l|l|}
\hline Awal & Metode Kegiatan & Outcome \\
\hline Belum memahami manfaat & Pemahaman tentang & Pengembangan \\
usaha jamu gendong, belum & pentingnya manfaat usaha & produk Jamu \\
mengerti pengembangan & jamu gendong, keuntungan & Gendong. \\
produk jamu gendong, & menjadi anggota Kube, & \\
belum mengetahui tata cara & pengembangan produk \\
manajemen usaha jamu & Manajemen Usaha \\
gendong. & $\begin{array}{l}\text { pendampingan gendong, } \\
\text { pengembangan produk dan } \\
\text { manajemen usaha jamu } \\
\text { gendong. }\end{array}$ & \\
& & \\
\hline
\end{tabular}

\section{Kerangka Pemecahan Masalah}

Pendekatan yang ditawarkan untuk menyelesaikan permasalahan yang dihadapi adalah pendampingan Kube Jamu Gendong dengan memberikan penyuluhan dan pelatihan.

1. Pemahaman tentang pentingnya Jamu Gendong,

2. Penjelasan manfaat dan keuntungan Jamu Gendong bagi masyarakat pengkonsumsi jamu maupun bagi anggota Kube dalam menambah pendapatan keluarga,

3. Praktek dan penjelasan pembuatan ramuan Jamu gendong yang beragam produk seperti : Kunir asem, Beras Kencur, Cabe Puyang, Kunir Putih, Temulawak, Pegel Linu dan masih ada yang lain.

4. Penjelasan tentang manajemen usaha pada Kube Jamu Gendong Seger Waras.

5. Penjelasan inovasi produk jamu gendong agar memiliki daya saing terhadap jamu tradisional yang lain.

6. Mendampingi anggota Kube jamu gendong Seger Waras dalam melakukan manajemen usaha.

7. Mendampingi anggota Kube jamu gendong Seger Waras dalam melakukan inovasi produk.

8. Mencarikan instansi atau perusahaan untuk memberikan bantuan modal melalui program Corporate Social Responsibility (CSR).

\section{Khalayak Sasaran}

Khalayak sasaran yang strategis dalam kegiatan ini adalah ibu ibu anggota Kelompok Usaha Bersama (Kube) Jamu Gendong Seger Waras PKK di Grogol Kabupaten Sukoharjo, yang telah mengikuti kegiatan pengabdian, melalui penyampaian masalah dan pelatihan tentang jamu tradisonal atau yang biasa disebut dengan Jamu Gendong selama pendampingan yang telah diberikan oleh Tim Pengabdian Kepada Masyarakat.

\section{HASIL DAN PEMBAHASAN}

Kegiatan pengabdian kepada masyarakat yang diseleggarakan dan diawali dengan survey bersama Tim dosen dan mahasiswa STIE AUB Surakarta. Waktu Pelasanaan selama 5 (lima) bulan .

Setelah Tim Pengabdian Kepada Masyarakat STIE AUB Surakarta memberikan penjelasan, tentang pentingnya penambahan pendapatan keluarga melalui usaha rumahan, keuntungan melakukan usaha di rumah dari jamu tradisional, pendampingan manajemen usaha dan pendampingan pengembangan produk jamu tradisonal atau jamu gendong, maka diperoleh hasil: 
1. Selama memperoleh penjelasan dan pelatihan tentang hal tersebut para peserta penuh perhatian dan memperhatikan dengan seksama.

2. Para peserta memberikan tanggapan positif dalam mengikuti penyuluhan dan pelatihan, serta pendampingan yang dilakukan Tim PKM, saling bertanya jawab dan saling berdiskusi

3. Para peserta antusias untuk menjadi mengembangkan usaha di rumah dari bahan rempahrempah yang menjadi tamu tradisional atau jamu gendong.

4. Para peserta antusias untuk melakukan inovasi produk seperti :
a. melakukan penjualan jamu gendong yang dilakukan dengan sepeda,
b. membuka warung jamu di rumah maupun di pasar tradisional,
c. mengemas jamu tradisional dalam botol yang dititipkan diwarung-warung maupun pasar tradisional,
d. membuat jamu dalam bentuk kering atau ditumbuk halus dan dikemas dalam sachet plastik,
e. melakukan inovasi pengemasan pada jamu dengan botol atau plasik sachet yang lebih bagus,
f. melakukan inovasi campuran berbagai rempah-rempah agar terjadi produk dengan rasa yang khas atau berbeda dan disukai masyarakat.

5. Para peserta antusias untuk untuk melakukan manajemen usaha yang lebih baik, seperti :
a. pemilihan bahan baku yang lebih baik kualitasnya,
b. mengadakan pembukuan keuangan
c. melakukan perluasan pasar dan jam operasi yang lebih lama, seperti buka gerai di sore hingga malam hari.
d. menitipkan jamu gendong pada café dan HIK yang berada di area jangkauan.

6. Pelaksanaan berlangsung tertib dan berjalan dengan baik sesuai jadwal.

Dari workshop dapat diketahui bahwa:

1. Para peserta belum mengetahui manfaat jamu tradisional bagi kesehatan masyarakat secara umum, terutama dapat meningkatkan daya tahan tubuh pada masa endemic wabah covid19 saat ini.

2. Peserta belum banyak yang melakukan manajemen usaha yang lebih baik.

3. Para peserta perlu banyak informasi tentang makna Inovasi produk dan contohnya agar produk semakin banyak disukai masyarakat, sehingga terjadi penjualan yang meningkat dan akhirnya akan meninggikan pendapatan keluarga.

4. Para peserta perlu informasi terobosan kerjasama agar produk jamu tradisioanl atau jamu gendong menyasar pada masyarakat klas social menengah ke atas.

\section{SIMPULAN}

Dari kegiatan PKM ini bisa dibuat kesimpulan sebagai berikut :

1. Sebagian peserta belum mengetahui manfaat yang lebih luas dari jamu tradisional atau jamu gendong ini.

2. Sebagian besar peserta belum mengetahui manajemen usaha pada jamu tradisional atau jamu gendong.

3. Sebagian besar peserta belum mengetahui pengembangan produk jamu tradisional atau jamu gendong, yang akan meninggikan minat masyarakat.

4. Perlunya peningkatan pendampingan pengembangan produk jamu gendong.

5. Perlunya peningkatan pendampingan manajemen usaha pada usaha jamu gendong.

6. Perlunya memberikan pengetahuan tentang keuntungan saat para peserta dapat melakukan manajemen usaha yang baik dan pengembangan produk pada usaha jamu gendong. 
7. Perlunya memberikan pengetahuan tentang melakukan kerjasama dengan pihak luar agar jamu gendong ini lebih luas lagi pengkonsumsinya.

\section{E. SARAN}

1. Kegiatan Pengabdian Kepada Masyarakat ini hendaknya tidak berhenti hanya sampai disini saja, tetapi ada tindak lanjut sehingga terjalin kerjasama yang berkesinambungan antara Tim Pengabdian Kepada Masyarakat dengan ibu ibu kelompok usaha Jamu gendong Seger Waras PKK di Grogol.

2. Mencarikan perusahaan untuk memberikan bantuan modal melalui program Corporate Social Responsibility (CSR).

3. Pengabdian yang akan datang dapat dikembangkan

4. Secara periodik diadakan sharing antara masyarakat dengan penguasa desa, akademisi dan praktisi untuk membahas permasalahan permasalahan

\section{DAFTAR PUSTAKA}

Jay Heizer,Barry Render, 2009, Operation Managemen, Manajemen Operasi, Buku 1 Edisi 9, Jakarta : Salemba4.

Setyawati, Y., \& Hermawan, S. (2018). Persepsi Pemilik dan Pengetahuan Akuntansi Pelaku Usaha Mikro Kecil dan Menengah (UMKM) atas Penyusunan Laporan Keuangan. Riset Akuntansi dan Keuangan Indonesia, 3(2).

Galuh, Ajeng Kartika. 2008. Peran Koperasi Simpan Pinjam dan Efektifitas Kredit Koperasi Simpan Pinjam dalam Meningkatkan Kesejahteraan Masyarakat Pedesaan (Suatu Studi di Desa Prambon Kecamatan PrambonKabupaten Sidoarjo).

Kartasapoetra, dkk.2003. Praktek Pengelolaan Koperasi. Jakarta: Rineka Cipta.

Ruzz Media.Hendar dan Kusnadi. 2005. Ekonomi Koperasi. Jakarta: Lembaga Penerbit Fakultas Ekonomi Universitas Indonesia.

Undang - Undang Nomor 20 tahun 2008 tentang Usaha Mikro, Kecil dan Menengah.

https://www.jogloabang.com. Permensos No.2 Tahun 2019, Bantuan UEP kepada KUBE untuk Penanganan Fakir Miskin

Resolusi 2020, Kemensos

http://ammarawirausaha.blogspot.com/2011/03/kemasan-yang-digunakan-untukmembungkus.html

https://bisnisukm.com/jamu-gendong-masih-dicari-dan-diminati.html

https://m.liputan6.com/health/read/3225519/mengapa-jamu-gendong-tak-perlu-izin-edar-simakpenjelasan-bpom

https://m.wartaekonomi,co.id/berita201264/jamu-gendong-badan-tambah-sehat-ekonomipinggiran-makin-terdorong 